\title{
Czego nauczył nas Bortnowski?
}

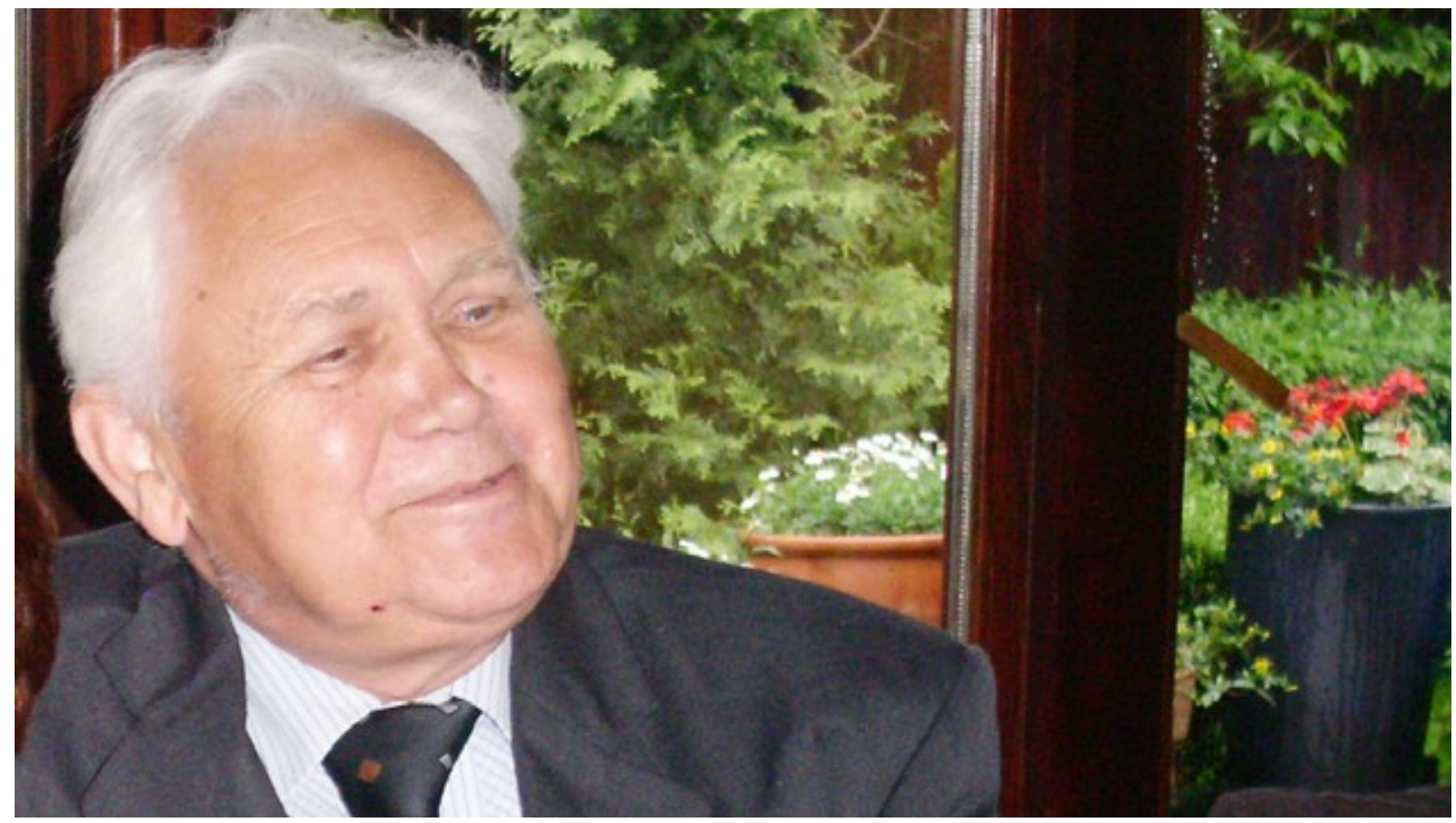

Panel poświęcony doktorowi Stanisławowi Bortnowskiemu rozpoczynał seminarium organizowane 8 czerwca 2015 r. na Wydziale Polonistyki Uniwersytetu Jagiellońskiego w ramach realizacji projektu MNiSW „Akademickie Centrum Kreatywności”. W rozmowie udział wzięli uczniowie i przyjaciele Stanisława Bortnowskiego (Jadwiga Kowalikowa, Anna Pilch, Zofia Budrewicz, Ewa Jaskółowa, Witold Bobiński, Agnieszka Kania. Panel prowadziła Anna Janus-Sitarz - kierownik projektu ACK)

\section{Anna Janus-Sitarz:}

Nie bez powodu seminarium zatytułowane „Twórczy nauczyciel twórczy uczeń" rozpoczynamy od panelu poświęconego zmarłemu rok temu doktorowi Stanisławowi Bortnowskiemu. Sam niezwykle kreatywny, tropił i popularyzował wszelkie przejawy kreatywności w pracy nauczycieli polonistów, inspirował do niesztampowych metod kształcenia językowego, niebanalnych interpretacji utworów literackich, oryginalnych odczytań tekstów kultury, odważnego łamania schematów w nauczaniu. Uczył, jak wychować twórczego ucznia.

Przygotowując się do tego spotkania, po raz kolejny sięgnęłam do książek mojego mistrza. Mam dla nich oddzielną półkę. Prawie wszystkie 
z dedykacją, czasem - zawstydzającą wobec jego niespożytej energii i pracowitości, czasem mobilizującą do pracy niezasłużoną pochwałą. Często jednak - dodającą skrzydeł i wzmacniającą poczucie własnej wartości.

Przeglądam ulubione tomy: Spór z polonistyka szkolna, Scenariusze półwariackie czyli poezja współczesna w szkole, Warsztaty dziennikarskie, Ferdydurkizm czyli Gombrowicz w szkole, Zdziwienia polonistyczne czyli o sztuce na lekcjach polskiego, Przewodnik po sztuce uczenia literatury i wiele innych. Czytam w Jak uczyć poezji?:

Zatem praca z poezją powinna się także rodzić z natchnienia, z jakiegoś arcydziwnego, arcyszaleńczego, arcymądrego pomysłu. Lekcja z poezji to jakby tworzenie sytuacji lirycznej, ucieczka z normalnego świata w kierunku innej wyobraźni. Albo scenariusz teatralny. Albo pomysł happeningu. Albo równanie matematyczne. Trochę logiki, dużo wariactwa, najwięcej improwizacji. Lub odwrotnie: dużo rozsądnego myślenia, mało spontaniczności i jeszcze mniej rozsądku. Od chwytów ku racjonalności. Od nastroju do wiedzy. Od swobody do precyzji. ${ }^{1}$

Kiedy trafiłam na ten fragment, nie mogłam się oprzeć zdziwieniu: To Bortnowski napisał? Nie - ja? A skoro to on, a nie ja, to znaczy, że piszę, mówię i myślę jego słowami. Oczywiście, właśnie tak należy uczyć poezji! Tak należy pisać o tym uczeniu. Przypuszczam, że wielu nauczycieli czytających jego książki, niejednokrotnie miało identyczne wrażenie, że Bortnowski werbalizuje nasze odczucia i poglądy. My też moglibyśmy coś podobnego na dany temat powiedzieć, ale on wyraża to trafniej, sugestywniej, bardziej błyskotliwie i przekonująco. Swoim autorytetem umacniał nas w przekonaniu, że warto walczyć ze szkolną rutyną, nawet narażając się na nieprzychylność przełożonych lub krytyków.

Przytaczam kolejny cytatz książkipod znamiennym tytułem: Nauczycielu, $B A D Z ́$ SOBĄ! , którą polecam swoim studentom już na pierwszych zajęciach metodycznych, wskazując na teksty przestrzegające przed pokrywaniem się „śniedzią belferską”, przed zniechęcaniem uczniów do literatury, przed biurokratyzacją konspektów.

Tym razem zatrzymał mnie następujący fragment:

Lat temu piętnaście, gdy pracowałem nad swoją pierwszą książeczką i chciałem ją zatytułować: „Nie bądź nudny, nauczycielu!”, otrzymałem ostrą reprymendę: „Jakże to, kolego Bortnowski, taki młody nauczyciel ośmiela się pouczać starszych, bardziej doświadczonych i jeszcze zwraca się w formie rozkazującej!”

Ustąpiłem z tytułu na nijakie „Na tropach szkolnej polonistyki”, czego po dziś dzień jako publicysta żałuję. Po latach, gdym siwy i leciwy, ośmielam się wrócić do impertynenckiego tytułu, stąd hasło: „NAUCZYCIEU, NIE DYKTUJ!”2.

Nie mogę pominąć tego niezwykle aktualnego apelu o zaprzestanie dyktowania. Po 30 latach od jego ogłoszenia badania wskazują, że wciąż zastraszająco duża liczba polonistów stosuje ten najbardziej sprzeczny

\footnotetext{
1 Bortnowski Stanisław, 1991, Jak uczyć poezji, Warszawa, s. 7.

2 Bortnowski Stanisław, 1992, Nauczycielu, BĄDŻ SOBĄ!, Warszawa, s. 11.
} 
z zasadami efektywności nauczania sposób przekazywania wiedzy uczniom. Jednak to, co najbardziej przykuwa uwagę czytelnika w przytoczonym cytacie, to ten niewykorzystany przez autora tytuł. Zastanawiając się nieco dłużej, można stwierdzić, że na okładce każdej z 18 wydanych przez niego książek mógłby widnieć napis: „Nie bądź nudny, nauczycielu!”. Ta walka z nudą w nauczaniu stała się dla mnie jednym z najważniejszych przykazań, jakie starałam się wypełniać od pierwszych zajęć z doktorem Bortnowskim, najpierw jako studentka, którą uczył i hospitował, a później jako nauczycielka języka polskiego. Uświadomiłam sobie, że nie mógł to być przypadek, że pierwszy napisany przeze mnie (za namową Staszka), artykuł w „Polonistyce” poświęcony edukacji polonistycznej zaczynał się od słów: „Grzechem głównym nauczania (...) jest nuda." ${ }^{3}$

Jako była szkolna polonistka, a obecnie - nauczycielka przyszłych nauczycieli - zawdzięczam mu wiele. Nauczył mnie, że aby wymagać od innych, trzeba przede wszystkim być wymagającym wobec siebie, inspirował do nieustannej pracy, czytania i pisania kolejnych książek, ale także do podróży, poznawania nowych ludzi, galerii, spektakli, odkrywania nowych smaków i uroków małych miasteczek. Uczył pokory wobec własnej niedoskonałości, ale i dystansu wobec nadmiernej naukowości. Jako swoje przyjęłam jego przekonanie, że książek nie wolno pisać z myślą o recenzentach, lecz z myślą o czytelnikach, którym mogą się one przydać. Zarażał energią. Przede wszystkim jednak dzięki niemu zrozumiałam, że aby czerpać radość z pracy w szkole i na uniwersytecie, trzeba być twórczym i cieszyć się z twórczych dokonań innych: uczniów, studentów, doktorantów, współpracowników.

Jako mój wykładowca, a potem nieco starszy kolega i przyjaciel, wywarł na mnie wpływ ogromny. Tak jak i jego książki, z których inspiracje czerpały kolejne generacje szkolnych polonistek i polonistów. A jak postrzegali go inni? Poproszę o wypowiedzi dawną wieloletnią kierownik Katedry Polonistycznej Edukacji Nauczycielskiej Wydziału Polonistyki UJ, współpracującą z Bortnowskim przez blisko 40 lat, prof. dr hab. Jadwigę Kowalikową oraz obecnie kierującą Katedrą, prof. dr hab. Annę Pilch.

\section{Jadwiga Kowalikowa:}

O Stanisławie Bortnowskim można powiedzieć, że był nauczycielem kompletnym tak pod względem ilości i natężenia cech osobowościowych usposabiających go szczególnie do odnoszenia sukcesów dydaktycznych, jak i wielowymiarowego charakteru jego działalności zawodowej. Należałoby dodać jeszcze dla uzasadnienia twierdzenia wyjściowego takie wykładniki, jak wielość obszarów, w jakich przejawiał swą aktywność oraz imponująca liczba osób, które stały się jej podmiotami oraz beneficjentami.

Ze względu na ograniczoną objętość niniejszej wypowiedzi szczegółowe omówienie wymienionych cech, na co każda z nich zasługuje, musi zastąpić

3 Janus-Sitarz Anna, 1986, Zatańczmy „Balladynę”, czyli gry dramatyczne $w$ nowym programie nauczania języka polskiego w szkole, „Polonistyka”, nr 1, s. 42. 
ich rejestr. Wszyscy, którzy znali ich posiadacza, bez trudu potrafią wyliczankę tę wzbogacić stosownymi egzemplifikacjami:

- rozległa wiedza polonistyczna i humanistyczna,

- bogaty i wciąż rozwijany warsztat metodyczny,

- zdolność wchodzenia w wielorakie relacje społeczne w różnorodnych sytuacjach,

- empatia w stosunku do partnerów interakcji,

- umiejętność kierowania pracą zespołową w grupach o różnym składzie personalnym, a więc obejmujących uczniów, studentów, polonistów szkolnych, dydaktyków uniwersyteckich,

- zgodliwość - jako członka zespołu podejmującego wspólne przedsięwzięcia (zarówno stałego, jak np. zakład i katedra, jak i tworzonego okazjonalnie dla realizacji określonych zadań, jak np. komisja),

- nieustająca potrzeba bycia w dalszym ciągu osobą uczącą się przejawiająca się przez studiowanie literatury związanej z wykonywanym zawodem oraz śledzenie cudzych osiągnięć,

- szacunek dla dzieł i dokonań innych specjalistów, także tych, z których poglądami się nie zgadzał,

- wiarygodność głoszonych przekonań i ocen ujawniająca się zarówno przez zgodność słów i czynów, jak i stawianie innym tych samych wymagań, jakim sam potrafił sprostać,

- pozytywny stosunek emocjonalny do dziedziny, w której był specjalistą (dawał dowody autentycznego zainteresowania szeroko rozumianą polonistyką, humanistyką, szkołą jako swoistą instytucją, metodyką nauczania, zawodem nauczyciela, przy czym zainteresowanie to często miało temperaturę entuzjazmu),

- optymizm,

- żarliwe zaangażowanie $\mathrm{w}$ ruch edukacyjny i oświatowy potwierdzone publicznie licznymi i częstymi wypowiedziami zarówno mówionymi, jak i pisanymi,

- szybkość i intensywność reagowania na wszystkie zjawiska będące zarówno wykładnikami rozwoju i postępu w dydaktyce polonistycznej, jak i sygnałami ostrzegającymi przed błędami, niedostatkami i brakami wraz z ich negatywnymi konsekwencjami o wymiarze tak edukacyjnym, jak i społecznym,

- zdolność proponowania korzystnych rozwiązań pozwalających przezwyciężać lub przynajmniej łagodzić i neutralizować trudności i konflikty,

- dar rzeczowego oraz błyskotliwego polemizowania z oponentami z jednej strony, a z drugiej łatwość zjednywania sobie stronników i zwolenników dzięki sugestywności przekonywania o słuszności własnych racji, 
- talent dziennikarski i pisarski, który pozwolił mu stworzyć liczne wartościowe teksty, w tym kilka książek uznanych za dydaktyczne bestsellery,

- niewyczerpana inwencja w zakresie doskonalenia i unowocześniania polonistyki szkolnej i uniwersyteckiej,

- hojność w dzieleniu się z innymi swoimi pomysłami,

- brak uprzedzeń w zakresie poglądów na nauczanie, uczenie się, kształcenie nauczycieli polonistów oraz skłonności do konserwatyzmu oraz sceptycyzmu usprawiedliwianego wiernością tradycji i respektem dla autorytetów,

- życzliwe witanie wszelkich zmian i nowych propozycji w zakresie dydaktyki literatury i języka, któremu towarzyszyła gotowość weryfikacji oraz przekładania na własne pomysły metodyczne,

- wysoka kultura osobista, uprzejmość, takt.

Wszystkie wymienione cechy pozostawały w harmonii, a relacje te skutkowały wytworzeniem się synergii, co sprawiało, iż Stanisław Bortnowski był odbierany jako osobowość charyzmatyczna. Stąd też wynika jego popularność w środowisku dydaktyków szkolnych i uniwersyteckich, a także wśród studentów, na których wywierał ogromny wpływ. Dlatego darzyli go sympatią ludzie, którzy mieli możliwość bliżej go poznać. Zarówno ci, dla których był kolegą i partnerem, jak osoby uznające go za mistrza oraz autorytet.

Podobnie jak w przypadku cech osobowościowych także charakterystyka działalności zawodowej Stanisława Bortnowskiego z analogicznych przyczyn zostanie ujęta w lakonicznych punktach, które jedynie sygnalizują, a nie wnikliwie i szczegółowo omawiają. Dlatego wypada ponownie zwrócić się z prośbą o wyrozumiałość a także o dopełniające dopowiedzenie oraz konkretyzację podanych informacji przez przywołanie stosownej egzemplifikacji. Z pewnością znawcom jego prac nie będzie trudno prośbę tę spełnić. Oceniając wspomnianą działalność tego wybitnego dydaktyka i nauczyciela, należy zwrócić uwagę na:

- wiele obszarów, do których należy nauczanie uczniów i studentów, udzielanie porad czynnym zawodowo nauczycielom, tworzenie własnych koncepcji i rozwiązań metodycznych, dzielenie się swymi doświadczeniami za pośrednictwem licznych publikacji, reagowanie przez uprawianie publicystyki oświatowej na bieżące wydarzenia i palące problemy szkoły jako instytucji oraz szeroko rozumianej polonistyki zarówno szkolnej, jak i uniwersyteckiej,

- różnorodność oraz ogromną liczbę podmiotów, jednostek i grup, z którymi miał kontakty i którym służył, pełniąc wymienione role,

- udowodnienie na własnym przykładzie specjalisty wszechstronnego i uniwersalnego, iż przeprowadzana na gruncie pedeutologii klasyfikacja nauczycieli przez wyodrębnianie wśród nich różnych typów 
osobowościowych to zabieg sprawnie porządkujący przedmiot badań, ale nie zawsze zgodny z rzeczywistością .

Trzeba Stanisława Bortnowskiego cenić za to, jakim był człowiekiem, badaczem, nauczycielem, dydaktykiem uniwersyteckim, nauczycielem i mistrzem przyszłych nauczycieli oraz za to, co osiągnął. Należy również korzystać z jego dorobku, traktować jego pomysły jako inspirację do poszukiwania własnych rozwiązań. Nie przyniesie też ujmy nikomu, kto obrał sobie dydaktykę polonistyczną jako obszar swej aktywności, jeżeli spojrzy na autora książek stanowiących kanon literatury przedmiotowej, z którymi winien się koniecznie zapoznać. Warto uczyć się od Stanisława Bortnowskiego, jak być nauczycielem.

\section{Anna Pilch:}

Czego nauczył mnie Stanisław Bortnowski? Odpowiadam bez zastanowienia i bez żadnych wątpliwości.

1. Patrzenia na literaturę $\mathrm{w}$ taki sposób, by jej wartość, piękno i sens przekazać modemu odbiorcy; szacunku dla tradycji przy jednoczesnej konieczności poszukiwania współczesnego spojrzenia; rozsądku łączenia klasyki literackiej z koniecznością współczesnego przekazywania jej w sposób ciekawy, atrakcyjny i kreatywny; czytania z sensem, z pasją, która była w nim przez całe życie, z rozsądnym umiarem, z akcentowaniem własnego zdania, które nie burzy piękna literackiego i artystycznego dzieła, a wręcz przeciwnie: wydobywa je i podkreśla.

2. Stanisław Bortnowski napisał bardzo dużo ważnych dla metodyki, polonistyki, nauczyciela, ucznia, studenta książek, ale szczególnie dwie chciałabym wyeksponować w mojej, pozostawionej przez Niego bibliotece. Pierwsza, to Zdziwienia polonistyczne, druga Przewodnik po sztuce uczenia literatury. Te dwie pozycje oddają całą przestrzeń jego dydaktycznych dokonań.

3. Dzisiaj przemiany w polonistycznej dydaktyce szkolnej (na przykład wprowadzona w roku 2015 nowa matura) są dowodem na to, o czym pisał zawsze. Bowiem książkę o randze kontekstów wizualnych dla lepszego rozumienia literatury opublikował w latach 80.: „Konteksty są po to, by mądrzej, szerzej i wnikliwiej interpretować utwory zamieszczone w kanonie lektur szkolnych" - pisał w Kontekstach dzieła literackiego. Już wtedy mówił o integracji sztuk, o potrzebie komplementarnego czytania tekstów kultury: „Konteksty interpretacyjne przeciwstawiają się samowystarczalności literatury". Mamy rok 2015 - i pamiętajmy, że Stanisław Bortnowski był i inicjatorem, i prekursorem, i jednocześnie twórcą przemian, jakie w polonistycznej szkolnej dydaktyce zaszły i ciągle zachodzą. 
4. Bortnowski wiedział, iż dla zrozumienia piękna dzieł literatury konieczne jest nieizolowanie jej od innych języków i znaków, w których wyrażają się sztuki piękne. Myślę, że dzisiejszą nową maturę pochwaliłby za słuszny kierunek zmian, ale mankamenty wypunktowałby precyzyjnie $\mathrm{z}$ tak charakterystyczną dla Niego i wiedzą, i pasją.

5. Bortnowski nauczył mnie wszystkich dobrych i mądrych rzeczy związanych z dydaktyką. Sprowadzał na ziemię moją skłonność do utopijnych czasem marzeń i pomysłów, by teorie literaturoznawcze wspomagały i wzbogacały sztukę interpretacji w szkole. Myślę o jego komentarzu do wnikliwie przeczytanej mojej książki Kierunki interpretacji tekstu poetyckiego. Literaturoznawstwo i dydaktyka. W Przewodniku po sztuce uczenia Bortnowski tak napisał:

To, co dla Pilch jest grzechem uczących, z którym należy walczyć, dla mnie jest to stan normalny, który się nie zmieni. Pilch próbuje odzyskać dla szkoły wspomniane teorie z dekonstrukcją włącznie, i jest to projekt ambitny, tymczasem gdyby na lekcjach języka polskiego rozsądnie myślało się i mówiło, to już byłoby dobrze, co nie znaczy, że gdzieś kiedyś w zapędzie badawczym polonista nie może wyłożyć tezy modnej w danej chwili lub odrzuconej niesłusznie do lamusa teorii.

Mogłabym uparcie z nim polemizować, ale po latach stwierdzam, że miał dużo racji. Rozsądek i umiar plus poszukiwania nowych rozwiązań, nowych dróg i metod. To w dydaktyce jest najważniejsze.

6. Trudności w uczeniu i czytaniu literatury i sztuki powstają i rosną w miarę czytania, w miarę zdobywania wiedzy i umiejętności, w miarę uczenia kogoś. Zrozumiałam, że nadmierna gorliwość i pokusa do coraz to większej integracji tekstów różnych sztuk, do mnożenia coraz to rozleglejszych i wielokrotnych kontekstów, które mają literackie dzieło oświetlać, mogą też obraz tego dzieła zaciemniać. Bowiem na poziomie uniwersyteckim człowiek jest już najczęściej całkowicie ślepy - cały pojęciowy stosunek do świata staje $\mathrm{w}$ poprzek prostemu i umysłowemu poznaniu, odbiorca sztuki szuka tylko relacji przedmiotowych, opisu bądź „romansu z tekstem". Analogie literackie, psychologiczne lub historyczne w nadmiarze zaciemniają pole widzenia, kierują uwagę na wszelkie zagadnienia dookolne, nie centralne. A centrum jest przecież najważniejsze. Tego właśnie nauczył mnie Bortnowski - by przedmiot głębokiego namysłu i trafnego wyboru tekstu i metody był w centrum pracy dydaktycznej. 


\section{Anna Janus-Sitarz:}

My - współpracujący ze Stanisławem Bortnowskim na co dzień w sposób naturalny korzystaliśmy z jego inspiracji, życzliwych, choć często krytycznych i zawsze merytorycznych uwag, z jego niebywałej pomysłowości i pracowitości. Jego artykuły i książki obowiązywały naszych studentów jako lektury obowiązkowe, na jego wykładach i seminariach magisterskich było niezwykle tłoczno. A jak postrzegany był Bortnowski i jego - dla wielu kontrowersyjny - dorobek na innych uczelniach? Proszę o podzielenie się swoimi doświadczeniami kierownik Katedry Dydaktyki Literatury i Języka Polskiego na Uniwersytecie Pedagogicznym w Krakowie, prof. dr hab. Zofię Budrewicz oraz kierownik Zakładu Dydaktyki Literatury Polskiej na Uniwersytecie Śląskim w Katowicach, prof. dr hab. Ewę Jaskółową.

\section{Zofia Budrewicz:}

O doktorze Stanisławie Bortnowskim - dydaktyku oraz nauczycielu trudno jest mówić „syntetycznie” przede wszystkim dlatego, że Jego dorobek naukowy jest rozległy i wielonurtowy. W jednej z książek (Jak uczyć poezji?) pisał o sobie: „Zawsze byłem krnąbrny polonistycznie i niepotulny w myśleniu o literaturze, zawsze bliższy publicystyce i dalszy nauce”. Nie dajmy się jednak zwieść tym lub innym Jego słowom (o „rozwichrzonej publicystyce, którą uprawiam po błazeńsku”, Spór z polonistyka szkolna). Trudno znaleźć publikacje z dydaktyki polonistycznej, w których autorzy nie odwoływaliby się do tez i argumentacji autora "Potopu” $w$ szkole. Ściśle powiązane z fundamentalnymi dla praktyki polonistycznej zagadnieniami i podporządkowane zasadzie non scholae saed vitae discimus, wyrastały z świetnej orientacji nie tylko w prawidłowościach procesów kształcenia polonistycznego, ale również w ich stale zmieniających się uwarunkowaniach.

Na jednej z konferencji podkreślał dobitnie: „Zmienił się obieg kultury. Tkwimy w obiegu kultury masowej, zagarnia ona naszą wyobraźnię, nie ma już czasu na pogłębioną lekturę pisarzy" (Po co Sienkiewicz, Warszawa 2007). Z wielką energią i konsekwencją szukał najskuteczniejszych sposobów nauki samodzielności analityczno-interpretacyjnej. Bo przecież, twierdził, nikt nie pokochał poezji przez cudze interpretacje. Do tego potrzebne jest własne zdanie „ułożone z własnych, a nie cudzych słów”. Energicznie polemizował ze szkolnym kultem teorii literatury; uważał, że jej nadmiar grozi pustką intelektualną, ponieważ unicestwia indywidualne przeżycie estetyczne. Rozgraniczał wartość nauki literatury od nauki o literaturze, ponieważ „reguły sensu” nie mogą stawać się „ważniejsze niż sam sens”. Sprzeciwiał się strukturalistycznym „ucieczkom” od historii literatury oraz unieważnianiu biografii twórcy. Dziwił się „niechęci wobec wartościowania, bezosobowym sądom o poezji”, obojętności na normy estetyczne czy „Czystości i higieniczności warsztatu badawczego" polonisty.

$\mathrm{Z}$ całą mocą sprzeciwiał się również uproszczeniom wychowawczym lekcji literackich. Instrumentalne (propagandowe) wyzyskiwanie arcydzieł 
dla „konieczności wychowania” (Spór z polonistyka szkolna) uważał za niedopuszczalną jednostronność w pracy z lekturą, wychowywanie á rebours, w którym literatura traci swoją „estetyczną niepodległość”, a w konsekwencji gubi związek z celami „życiowymi” czytelnika.

W ostatnim referacie przygotowanym na I Kongres Dydaktyki Polonistycznej (którego nie mógł już wygłosić), Bortnowski z całą mocą podkreślał, że „pokolenia Google” trzeba uczyć szczególnie „barwnie, pomysłowo”; że lekcje "muszą mieć coś z widowiska, reklamy, happeningu”, słowem - ze scenariuszy, które naśladują życie. Wtedy zwiększają się szanse na przełamywanie bierności i bezkrytycyzmu młodych odbiorców tekstów kultury.

Moja droga do akceptacji takiego myślenia o dydaktyce lektury musiała rozłożyć się na etapy. Jako początkujący dydaktyk, który swój warsztat kształtował pod wpływem metodologicznej precyzji w planowaniu każdego badanego zagadnienia, perfekcji narzędzi badawczych, w tym języka pojęciowego (Jana Polakowskiego, Zenona Urygi, Anny Dyduchowej) oraz praktykowania strukturalnych metod czytania, dochodziłam stopniowo do akceptacji „żywiołu” lekcji - spontanicznego zdarzenia czy widowiska. Stopniowo odkrywane i wyraziście artykułowane przez Niego słabości „chłodnych” analiz strukturalnych utwierdzały mnie w przekonaniu (z pomocą studiów nad polonistyką międzywojenną, zwłaszcza Wóycickiego, Szyszkowskiego) o fundamentalnym znaczeniu nauczycielskich działań (strategii, metod, technik) motywujących ucznia do czytania lektury.

Nie jest przesadne stwierdzenie, że Bortnowski całe swoje życie naukowo-zawodowe poświęcił tej właśnie sprawie. Książki: Jak uczyć poezji? i Konteksty kulturowe dzieła literackiego wciąż inspirują polonistów do rozwijania postaw kreatywnych. Ale ich wartość „teoretyczno-praktyczna" jest, co trzeba podkreślić, znacznie większa. Nie zdezaktualizowała się przecież wiedza o znaczeniu strategii operacyjnej, uczeniu się przez działanie, żywe doświadczenie czy preferowanie problemowości w kształceniu literacko-kulturowym. Po dwudziestu kilku latach od wydania tych „książek konkretnych” w naukowej argumentacji o wyzwalaniu aktywności czy praktykowaniu uczniowskiej podmiotowości (cenne ilustracje technik jej stymulowania) nic się nie zmieniło. Przeciwnie, uzasadnienia Bortnowskiego nabrały jeszcze większego znaczenia. Dwa ostatnie cykle badań umiejętności uczniowskich (PISA) obnażyły niedostatki w stosowaniu grupowych form pracy oraz problemowego toku lektury. A te właśnie kwestie „od zawsze” zajmowały Bortnowskiego - dydaktyka i metodyka.

Sposoby samodzielnego ujawniania tajników wiersza („uczeń bez własnego zdania, to uczeń trochę kaleki”) pokazywał Bortnowski w swojej autorskiej, cenionej metodzie hipotezy interpretacyjnej, a także - w uczeniu dziecka stawiania dziełu pytań (bo to przywilej jego, a nie nauczyciela!). Tego ma nauczyć polonista, podkreślał, wykazując partnerską lojalność wobec cudzego trudu, ale i sam musi „uczyć się cierpliwie milczeć”. 
Dodajmy też uzasadnienia wartości lektury impresyjnej w szkole średniej (jak rozumieli je dydaktycy tej miary, co Wóycicki czy Lausz). Czytanie dzieła to przecież (Sartrowski) „,szereg hipotez, snów i następujących po nich przebudzeń, nadziei i zawodów". Nie oznacza to, że Badacz w ogóle negował rolę metod strukturalnej analizy dzieł artystycznych (podobnie jak nie przekreślał lekcji uporządkowanych w „dobrze znane ogniwa dydaktyczne”). Miał świadomość, że swobodna dyskusja nie jest w realizacji łatwa („nie spierając się o wartości, nigdy ich nie obronimy”), a impresyjność wymaga czytelniczej dojrzałości, którą osiąga się przez naukę sfunkcjonalizowanego odczytywania struktury tekstu.

Dziś wiemy na pewno, że nazwisko Stanisława Bortnowskiego to gwarancja propozycji metodycznych, które się w polonistyce nie starzeją. Prace pisane emocjonalnie, „zadziornie” ( $\mathrm{z}$ „wyostrzeniami i dobitnościami”), szybko zyskiwały i zyskują czytelników. Tezy, argumentacje i wnioski praktyczne łatwo zapadały w pamięć i stawały się ważnym składnikiem „wyposażenia" intelektualnego i warsztatowego polonisty. Każdy początkujący lub przygotowujący się do zawodu nauczyciel w nich szuka(ł) „pierwszej” pomocy w trudnych sytuacjach lekcyjnych. Wracało się do nich po latach, ale także na bieżąco śledzi(ło) prace najnowsze Bortnowskiego, bowiem Autor nigdy nie ukrywał, że modyfikuje swoje stanowisko, wycofuje się z twierdzeń, które nie znalazły uzasadnienia w późniejszej praktyce. Na przykład swoją koncepcję lekcji jako „romansu z tekstem” Badacz uznał po latach za niejasną, sztuczną, nazbyt afektacyjną. Romans, konstatował, wymaga dojrzałości; możliwy jest na poziomie nauki w liceum, ale nie w szkole podstawowej (Spór z polonistyka szkolna). Zwłaszcza na tym poziomie edukacji ( $\mathrm{w}$ badaniach dydaktycznych ciągle zaniedbywanym) obnażał słabości majoryzowania metod heurystycznych; przez dokładne zapisy przebiegu takich lekcji pokazywał ich karykaturalność, kompletne oderwanie od potrzeb dziecięcego dialogu na lekcjach literackich. Takie godziny polskiego nie mają elementarnego związku z naśladowaniem życia i skutecznie blokują zainteresowania czytelnicze dziecka.

Fenomen popularności praczdydaktykiliteratury/kultury Bortnowskiego tkwi w ich uniwersalnym charakterze. To książki „o metodyce konkretnej”. Przez dziesięciolecia zachowują aktualność, ale i świeżość argumentacji, zwłaszcza dziś, gdy rzeczywistość staje się coraz bardziej „literaturze nieprzychylna". Inspirują polonistę do przemyśleń, jak być nauczycielem kreatywnym, czyli jak przekraczać „próg przeciętności”. Dzięki takim umiejętnościom „metodyka nabiera smaku, a może inaczej - staje się stylem. Styl zaś nie może opierać się na schematach" (Spór z polonistyka szkolna). Może więc to, czego nauczył nas Stanisław Bortnowski, najlepiej wyraża właśnie „metodyka polonistycznego stylu”? 


\section{Ewa Jaskółowa:}

Była druga połowa lat 80., może rok 1986, a może 1987. Jako młoda adiunkt, krótko po doktoracie, uczestniczyłam w konferencji organizowanej przez Uniwersytet Pedagogiczny w Krakowie (wówczas jeszcze Akademię Pedagogiczną), poświęconej badaniom edukacyjnym i nauczaniu języka polskiego - słynnej już dziś - „Jesiennej Szkole Dydaktyków”. I tu nastąpiło moje pierwsze spotkanie z Doktorem Stanisławem Bortnowskim. Wyszłam ze „śląskiej szkoły interpretacji” z mocnymi podstawami myślenia strukturalistycznego i byłam przekonana, że wyposażenie ucznia w narzędzia odbioru poezji, wyrosłe z tej metodologii, ułatwią każdemu zrozumienie najodleglejszych utworów poetyckich. Mój referat dotyczył możliwości zrozumienia przez uczniów barokowej koncepcji wiersza, a w konsekwencji uzmysłowienia barokowej idei życia dworskiego. Podstawą wystąpienia był wiersz Andrzeja Morsztyna pt. Niestatek, jeden z moich ulubionych tekstów tego autora, doskonale poddających się strukturalnej analizie, która pozwala na wykazanie funkcjonalności zastosowanego konceptu, chiazmu jako podstawy tego konceptu z wydobyciem różnorakich układów paralelnych. Jak na naukowy referat przystało, wydobyłam w analizie wszystkie relacje i zależności wynikające $\mathrm{z}$ konstrukcji utworu, by w konsekwencji stwierdzić, że dobrze przeprowadzona z uczniami analiza doprowadzi do spostrzeżenia i odkrycia przez nich związków kultury barokowej z konwencją tworzenia poezji w tej epoce. Po moim wystąpieniu najpierw wypowiadali się profesorowie Zenon Uryga oraz Mieczysław Inglot, chwaląc różne elementy wywodu, po czym głos zabrał Stanisław Bortnowski. Rozpoczął słowami: „No to dość tej hagiografii. Proszę mi powiedzieć, na co uczniom ta cała nomenklatura: chiazmy, pleonazmy, koncepty itd. Uczeń ma zrozumieć tekst, ma go po prostu przeżyć". Tu oczywiście nastąpiła między nami wymiana zdań. Wiedziałam, że mój interlokutor jest przekonany o zbędności przeszczepiania na szkolny grunt myślenia strukturalistycznego. Wiedziałam o jego sporze w tej kwestii z Bożeną Chrząstowską, gdy grzmiał na łamach „Polonistyki”: „Mickiewicz nie pisał komunikatów!”. Zwrócił się wprawdzie w tym samym periodyku: „Bożeno, miałaś rację” - ale to było już jakiś czas później. Tamtego wieczoru byłam przekonana o tym, że to ja mam rację. Z czasem zrozumiałam, że idea, jaką wyznawał Mistrz wielu pokoleń nauczycieli, wcale nie polegała na generalnym odrzuceniu współczesnych metodologii literaturoznawczych, lecz na rozsądnym przekładaniu ich na język szkolnej lekcji.

Stanisław Bortnowski był mistrzem prowokacji i od niej zawsze rozpoczynał uzmysławianie najtrudniejszych kwestii polonistycznych, tych związanych z etyką, estetyką i kompozycją tekstu literackiego. Postawa prowokatora ujawnia się nie tylko, w zwykle przekornych, wystąpieniach konferencyjnych, widać ją w polemikach drukowanych w "Polonistyce”, „Życiu Literackim” czy „Głosie Nauczycielskim”, ale przede wszystkim wjego publikacjach w części publicystycznych, w części naukowo-dydaktycznych. 
Czego nauczyłam się od Stanisława Bortnowskiego? Przekonał mnie, że teoria literatury niekoniecznie pełni pierwszorzędną rolę w szkolnej edukacji polonistycznej, utwierdził w przekonaniu, że pomysł na lekcję jest najważniejszą drogą do sukcesu nauczycielskiego. To dzięki spotkaniom z Nim oraz wielogodzinnym dyskusjom uświadomiłam sobie, że sztuka nauczania, to sztuka przekładu metodologii literaturoznawczych na działania metodyczne.

Dla Bortnowskiego podstawę lekcji stanowił pomysł. Dla mnie pomysł jest także ważny, ale podkreślam konieczność świadomości metodologicznej. Jest ona, w moim odczuciu, gwarancją przemyślanego, celowego, skierowanego na nauczenie interpretacji działania nauczyciela. I chyba w tej kwestii w jakimś momencie naszych spotkań sam Mistrz Bortnowski też się ze mną zgodził. Było mi miło, gdy po lekturze moich interpretacji poezji wyrażał się o nich pochlebnie.

Zostałam zaliczona do grona osóbjakoś związanych ze Staszkiem, zaczęliśmy zwracać się o siebie po imieniu. Stało się to chyba wówczas, gdy przyznałam się, że w dzieciństwie mieszkałam w Sztumie, małym miasteczku niedaleko Kwidzyna. Ale wspólnotę „doświadczenia geograficznego” wyznaczyła nam moja babcia, która pracowała w Kwidzyniu w tych samych latach, gdy On był tam nauczycielem języka polskiego w Liceum Ogólnokształcącym.

W ostatnich kilku latach miałam zaszczyt i honor należeć do grona takich osób, z którymi Staszek prowadził także mailową korespondencję świąteczną i podróżniczą. Byłam wśród adresatów jego pożegnalnego listu, w którym pisał do przyjaciół o swojej chorobie i godzeniu się z nią.

Nie był dla mnie „nauczycielem i mistrzem”, był starszym kolegą, który z własnej praktyki nauczycielskiej stworzył warsztat badacza, dydaktyka i dziennikarza. Upewnił mnie w przekonaniu, że zawód nauczyciela to nie tylko szlachetna misja, ale także sztuka, która potrzebuje Mistrzów.

\section{Anna Janus-Sitarz:}

Profesor Witold Bobiński najlepiej z nas znał doktora Bortnowskiego zarówno od strony zawodowej, jak i prywatnej.

\section{Witold Bobiński:}

Wspominanie Staszka Bortnowskiego zawsze będzie się dla mnie łączyło ze szczególnym wzruszeniem. Przez długie lata byliśmy związani rodzinnie, zawdzięczam mu bardzo wiele jako człowiek i jako dydaktyk, polonista. W znacznej mierze to właśnie Bortnowski sprawił, iż moją życiową przygodą i pasją stało się związane z polonistyką pisanie - podręczników, książek edukacyjnych, artykułów. On pierwszy namawiał mnie do spisywania dydaktycznych pomysłów. Jego wspaniałej żonie - Halinie - zawdzięczam pomysł napisania podręczników do historii i trwanie przy 
tym zamierzeniu. Myliłby się jednak ten, kto by sądził, iż zbawienny wpływ Bortnowskiego na moje zamiary twórcze polegał na namawianiu - wystarczyło bowiem, że w jednej ze swoich książek bohater naszej dzisiejszej rozmowy zacytował mój - jak dziś sobie przypominam - pierwszy tekst związany z dydaktyką polonistyczną - opublikowany w skromnej broszurze krakowskiego oddziału doskonalenia nauczycieli scenariusz lekcji poświęconej wierszowi Białoszewskiego. Skoro Bortnowski powołał się na mnie - stwierdziłem wówczas - to znaczy, że moje polonistyczne pomysły i moje pisanie są coś warte.

Więzy rodzinne sprawiły, że wiele czasu spędzaliśmy razem, a kto przebywał choćby jakiś czas ze Staszkiem Bortnowskim, wie, z jakim zapałem, twórczą radością i uporem pisał swoje kolejne teksty. Uświadamiam sobie dzisiaj, że to właśnie z Jego osobą będzie mi się już zawsze kojarzył stukot maszyny do pisania. Pisał właściwie bez przerwy, Przebywając w Jego otoczeniu i chcąc zachować twarz, właściwie nie można było pozostawać człowiekiem intelektualnie i poznawczo biernym, nie wypadało. Swoją aktywnością zarażał innych, dla leniwych pozostawał nieustannym wyzwaniem, trudnym do uspokojenia wyrzutem sumienia.

Co było i jest dla mnie Jego najważniejszym rysem osobowości jako człowieka twórczego, niepokornego i poszukującego, a zarazem jako polonisty niebywale - w kategoriach społecznych - potrzebnego i skutecznego? Odpowiedź będzie z konieczności skrótowa - tych cech było wszak wiele. Spróbuję wymienić tu te - według mnie - najważniejsze, bez specjalnej troski o hierarchizację:

- zdolność do zaskakiwania nieoczywistością rzeczy i zjawisk pozornie oczywistych, klarownych czy banalnych,

- wnikliwa natura dyskutanta, intelektualna przenikliwość,

- szacunek dla rzeczywistości, respektowanie jej praw,

- nienasycona ciekawość świata w jego najróżniejszych przejawach - zarówno tych ze sfery sztuki, jak i natury (jednakowo zresztą ludzkiej, jak i geograficzno-przyrodniczej),

- postrzeganie literatury jako jednego z wielu nurtów opowieści o świecie i człowieku - obok sztuki, architektury, muzyki,

- podróżnicza namiętność i niezaspokojona pasja zwiedzania,

- $\quad$ epikurejskie usposobienie i otwartość na innych.

Spostrzegawczość, przenikliwość i intuicyjne wyczucie tzw. zdrowego rozsądku sprawiały, że bardzo często rzeczywistość przyznawała rację poglądom czy zaledwie przeczuciom Staszka Bortnowskiego, o czym pewnie będziemy się przekonywać jeszcze wielokrotnie. Dotyczy to nie tylko koncepcji metodyki, jaką zarysował w swych publikacjach, ale także innych sfer ludzkich działań, np. sztuki czy życia społecznego. Pamiętam, gdzieś z samego początku lat 90., jeden z Jego żartów, nie tyle może wyszukany, ile zaskakujący siłą rażenia i świadczący o kapitalnym wyczuciu ducha 
czasów. Wróciwszy którymś popołudniem do domu, zakrzyknął głosem zdradzającym gwałtowne poruszenie:

- Słuchajcie, na Floriańskiej sprzedawali autobusy!

Osłupiałem. Człowiekowi dorastającemu w czasach PRL nie mieściło się wtedy w głowie, że prywatna osoba może mieć swój autobus. Zdawało mi się to nieprawdopodobne, a mimo to oczami wyobraźni widziałem już falującą i tłumną kolejkę amatorów tych wielkogabarytowych pojazdów, wciśniętą między kamienice na Floriańskiej. Uwierzyłem, choć przecież znałem upodobanie autora do surrealnych dowcipów. Wtedy na Floriańskiej autobusów, rzecz jasna, nie sprzedawali, ale już niebawem każdy z odpowiednią gotówką mógł sobie kupić nawet całą flotę. Kiedyś wszystko będzie na sprzedaż - mówił ten proroczy żart, choć naówczas wydawało nam się to tak odległe.

Epikurejskość, emocja, ekspresja, estetyka - słowami na „e” można by nader trafnie scharakteryzować sylwetkę (zarówno osobistą, jak i zawodową) Stanisława Bortnowskiego. Szacując jego wyjątkowość na firmamencie polskiej dydaktyki, przyjdzie nam dodawać jeszcze: „ewenement”.

\section{Anna Janus-Sitarz:}

$\mathrm{Na}$ koniec poproszę o głos przedstawicielkę młodszego pokolenia uczniów doktora Bortnowskiego, obecną doktorantkę, Agnieszkę Kanię.

\section{Agnieszka Kania:}

Mistrz to osoba, która wywiera ogromny wpływ na działania podopiecznego/wychowanka, pozostając dla niego autorytetem i niedoścignionym wzorem. Stanisław Bortnowski był moim Mistrzem - jako prowadzący grupę ćwiczeniową z metodyki, obserwator praktyk studenckich w liceum, promotor pracy magisterskiej, a potem zwolennik tego, abym połączyła pracę nauczycielki z działalnością naukową. Z powodu opóźniania się w czasie tej ostatniej idei (mimo nieustannej współpracy z Mistrzem, zawsze żywo zainteresowanym szkolną rzeczywistością) byłam przez niego często nazywana „córką marnotrawną” i rozliczana z podejmowanych działań. Do wyznaczonego osobą Mistrza ideału dąży się przez całe życie, ale najważniejsze, że ideał ten można określić.

Już pierwsze spotkania ze Stanisławem Bortnowskim uświadamiały, że propaguje on sposób nauczania języka polskiego bardzo odmienny od tego, do czego przyzwyczaiło mnie własne doświadczenie edukacyjne. Prowadzone przez niego zajęcia, pełne niespodzianek i „fajerwerków”, budziły ciekawość i inspirowały do twórczości, ale także wywoływały zachowawczą ostrożność: przecież na lekcji nie można aż tak szaleć, kiedyś trzeba przecież porządnie wszystkiego n a u c z y ć! Świadomość, że w tym szaleństwie jest metoda, miała przyjść z czasem. Szkolna codzienność pokazuje bowiem, że nie sposób prowadzić dziesiątków lekcji bez szukania urozmaicenia, czyli adekwatnych do grupy uczniów chwytów metodycznych 
czy nieszablonowych dróg interpretacji. Nie da się również pozostać kreatywnym nauczycielem bez nieustannego dokształcania się i wypróbowywania nowych metod pracy. Zasiane kiedyś ziarno „Polonisto, nie bądź nudny" (zwłaszcza w swoich własnych oczach, bo odbiorcy na szczęście zmieniają się co jakiś czas) okazało się skutecznym antidotum na grożącą w zawodzie rutynę.

Pozostający blisko polonistyki szkolnej i nauczycieli, zawsze chętnie biorący udział w spotkaniach krakowskiego Stowarzyszenia Polonistów, Stanisław Bortnowski był człowiekiem niebywale życzliwym i przy każdej okazji mającym dobre słowo dla tych, z którymi rozmawiał. Nikogo nie oceniał źle, co najwyżej wpadał w stan zadziwienia nad rozwiązaniami dalekimi od dobrego nauczania. Nie gniewał się na swoich oponentów, był zwolennikiem metodycznego pluralizmu nie tylko w teorii. Zadziwiająca była jego umiejętność pochwały studentów (np. za „arcyfrekwencję na zajęciach”) i motywowania do pracy, do znajdowania nowych rozwiązań. Nagrodą za twórczość była publikacja materiałów w jego książkach, dająca adeptom sztuki nauczania poczucie niesłychanego wyróżnienia i będąca powodem do dumy. Bo Mistrz, dobrze znając swoją wartość, nie musiał nikomu udowadniać, że jest najlepszy - potrafił docenić cudze odkrycia i dokonania, przyznać się, że jemu jakiś pomysł nie przyszedł do głowy.

Był prawdziwym humanistą i afirmował życie, znajdując czas nie tylko na spotkania z nauczycielami w różnych częściach Polski, ale także na przesyłanie noworocznych życzeń, opisów wakacyjnych wędrówek czy relacji z oglądania transmisji nowojorskich oper. Lista jego aktywności, o których chętnie opowiadał, była godna pozazdroszczenia i poświadczała, że rozumiał bardzo dobrze epikurejskie Carpe diem.

Stanisław Bortnowski wielokrotnie wyprzedzał swój czas, a jego idee z biegiem lat trafiały na lekcje i stawały się edukacyjną oczywistością. Dlatego znajomość z nim i lektura jego książek były gwarancją dostępu do tego, co w dydaktyce najbardziej nowoczesne, choćby za nowoczesność trzeba było uznać powrót do sprawdzonej tradycji, dla której miał dużo szacunku. Nie ma chyba polonistycznego tematu, którego nie poruszyłby w swoich licznych książkach i artykułach. Mistrz - także autoironii - pozwalał sobie i na zakładanie korony, i na żarty z samego siebie, zatem pewnie z radością i równocześnie przymrużeniem oka przyjąłby diagnozę, że - w dobrej dydaktyce polonistycznej - „my z niego wszyscy”.

\section{Anna Janus-Sitarz:}

Dziękując wszystkim za udział w panelu, pozostaje mi wyrazić nadzieję, że z książek, które nam Bortnowski zostawił, długo jeszcze czerpać będą inspiracje i zapał do pracy kolejne pokolenia nauczycieli. 
